\title{
De Limburgse arbeidsmarkt 2002-2006
}

Citation for published version (APA):

Researchcentrum voor Onderwijs en Arbeidsmarkt, ROA. (2003). De Limburgse arbeidsmarkt 2002-2006:

Beknopte rapportage. Researchcentrum voor Onderwijs en Arbeidsmarkt, Faculteit der Economische

Wetenschappen. ROA Reports No. 003 https://doi.org/10.26481/umarep.2003003

Document status and date:

Published: 01/01/2003

DOI:

10.26481/umarep.2003003

Document Version:

Publisher's PDF, also known as Version of record

\section{Please check the document version of this publication:}

- A submitted manuscript is the version of the article upon submission and before peer-review. There can be important differences between the submitted version and the official published version of record.

People interested in the research are advised to contact the author for the final version of the publication, or visit the DOI to the publisher's website.

- The final author version and the galley proof are versions of the publication after peer review.

- The final published version features the final layout of the paper including the volume, issue and page numbers.

Link to publication

\footnotetext{
General rights rights.

- You may freely distribute the URL identifying the publication in the public portal. please follow below link for the End User Agreement:

www.umlib.nl/taverne-license

Take down policy

If you believe that this document breaches copyright please contact us at:

repository@maastrichtuniversity.nl

providing details and we will investigate your claim.
}

Copyright and moral rights for the publications made accessible in the public portal are retained by the authors and/or other copyright owners and it is a condition of accessing publications that users recognise and abide by the legal requirements associated with these

- Users may download and print one copy of any publication from the public portal for the purpose of private study or research.

- You may not further distribute the material or use it for any profit-making activity or commercial gain

If the publication is distributed under the terms of Article $25 \mathrm{fa}$ of the Dutch Copyright Act, indicated by the "Taverne" license above, 


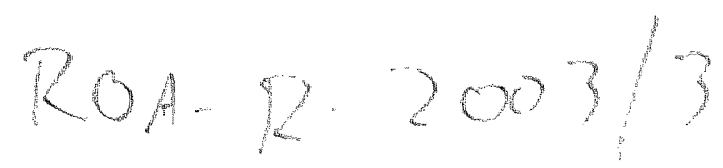

De Limburgse arbeidsmarkt 2002-2006

Beknopte Rapportage

Een uitgave van RAIL

(Regionale Arbeidsmarkt Informatie Limburg) 


\title{
RAIL 2002 is financieel mogelijk gemaakt door:
}

Centrum voor Werk en Inkomen:

CW1 afdeling Arbeidsmarktkennis en advies Zuidoost Nederlland

\author{
Limburgse gemeenten: \\ Maastricht \\ HeerlenSittard-Geleen \\ Weert \\ Roermond \\ Venlo \\ Venray \\ Limburgs bedrijfsleven: \\ DSM
}

Stg. Maakt 't in de Techniek

Zorg aan Zet

Kamer van Koophandel Limburg Noord

Kamer van koophandel Zuid-Limburg

Limburgs beroepsonderwijs:

Arcus College

Leeuwenborgh Opleidingen

Gilde Opleidingen

AOC Limburg

Provincie Limburg

\section{Bronnen}

03.RAlL-37: De Limburgse arbeidsmarkt 2002-2006; hoofdrapport (ROA)

03.RAIL-38: De Limburgse arbeidsmarkt 2002-2006; statistische bijlage (ROA)

03.RAIL-39: De Limburgse arbeidsmarkt 2002-2006; rayonrapportage Maastricht en Mergelland (Etil)

03.RAIL-40: De Limburgse arbeidsmarkt 2002-2006; rayonrapportage Parkstad Limburg (Etil)

03.RAlL-41: De Limburgse arbeidsmarkt 2002-2006; rayonrapportage Westelijke Mijnstreek (Etil)

03.RAlL-42: De Limburgse arbeidsmarkt 2002-2006; rayonrapportage rayon Roermond (Etil)

03.RAll-43: De Limburgse arbeidsmarkt 2002-2006; rayonrapportage rayon Ween (Etil)

03.RAIL-44: De Limburgse arbeidsmarkı 2002-2006; rayonrapportage rayon Venlo (Etil)

03.RAll-45: De Limburgse arbeidsmarkt 2002-2006; rayonrapportage rayon Venray (Etil)

\section{Colofon}

Vormgeving omslag: Lenting en Terlingen Grafisch Ontwerp

Lay-out, dtp en druk: Unigraphic, Universiteit Maastricht

Tekst:

Oplage

CWI Zuidoost Nederland, afd. Arbeidsmarktkennis $\&$ advies

ISBN:

1300 exemplaren

$90-5681-162-2$ 


\section{Voorwoord}

Voor $u$ ligt de zesde set van publicaties van het project Regionale Arbeidsmarkt Informatie Limburg (RAIL): De Limburgse arbeidsmarkt 2002-2006. De publicaties zijn samengesteld door het Researchcentrum voor Onderwijs en Arbeidsmarkt (ROA) en het Etil, beide verbonden aan de Universiteit Maastricht. Evenals vorig jaar bestaat deze jaargang uit tien delen, waaronder de beknopte rapportage, het hoofdrapport, de statistische bijlage en zeven rayonrapportages. Qua methodiek en aanpak ligı de uitgave in de lijn van voorgaande jaren: actueel, vernieuwend en oplossingsgericht.

$\mathrm{Na}$ jaren van economische voorspoed is thans het tij gekeerd en is de economische groei vrijwel tot stilstand gekomen. Dit heeft gevolgen voor de Limburgse arbeidsmarkt. In oktober 2002 is het aantal openstaande vacatures ongeveer de helft van $1 \frac{1}{2}$ jaar daarvoor, en is het aantal werkzoekenden met bijna $20 \%$ gestegen. Inmiddels is bekend dat de werkloosheid na oktober 2002 fors is blijven stijgen.

De huidige omslag op de arbeidsmarkt makt duidelijk dat adequate en actuele arbeidsmarktinformatie onmisbaar blijft. Middels het project Regionale Arbeidsmarkt Informatie Limburg (RAIL) heeft Limburg op dit vlak een reputatie opgebouwd. In géén enkele provincie in Nederland is zoveel geschikte arbeidsmarktinformatie voorhanden. Actuele informatie, korte en lange termijn prognoses, verdeeld naar opleiding, beroep, sector en rayon. Voor elk wat wils dus.

De informatie is niet alleen beschikbaar, ze wordt ook gebruikt. Dit bleek uit de klantmeting die naar aanleiding van de voorgaande uitgave is verricht. Naast hel gebruik via www.railsite.nl worden jaarlijks circa vier duizend publicaties verzonden aan ruim duizend personen of instellingen. De RAlL-publicaties en de Website worden tezamen zo'n 16 duizend keer per jaar geraadpleegd. Daarnaast wordt de helpdesk RAIL zo'n 200 keer per jaar bevraagd, worden er zo"n 20 RAIL-presentaties per jaar gegeven en verschijnen er jaarlijks circa 20 berichten in dag- en tijdschriften. Deze informatie wordt gebruikı ter algemene oriëntatie, maar ook om bijvoorbeeld beslissingen te nemen over het al dan niet opstarten van een nieuwe opleiding, doorstroming in het onderwijs te bevorderen, sectoren rayonplannen te onderbouwen, projecten op te starten e.d.

Het grote gebruik van RAll-informatie is mede te danken aan de opzet van hel project. Vanal het begin zijn allerlei partijen betrokken, zoals het Centrum voor Werk en Inkomen, de Limburgse gemeenten, het Limburgs Beroepsonderwijs, het Limburgs Bedrijfsleven en de Provincie Limburg. Met ingang van 2003 word de verwevenheid met relevante (beleids-) actoren nog verder vergroot, door de aanhaking bij het Vertrouwenspact Werkgelegenheid Limburg. Nu het project onder verantwoordelijkheid van het Vertrouwenspact plaatsvindt, is nog beter gewaarborgd dat de resultaten van het onderzoek worden benut voor het voeren van gefundeerd en gedeeld arbeidsmarktbeleid in de provincie Limburg. Zeker nu de werkloosheid stijgt is dit hard nodig.

Het project Regionale Arbeidsmarkı Informatie Limburg (RAIL) maakt de arbeidsmarkt transparanter en het arbeidsmarktbeleid consistenter. Daarom zijn wij ervan overtuigd dat 
RAlL ook de komende jaren een solide basis zal vormen voor het vinden van de juiste oplossingen voor knelpunten op de Limburgse arbeidsmarkt. Wij zijn vol vertrouwen dat RAlL nu in goede handen is bij het Vertrouwenspact Werkgelegenheid Limburg.

Aftredend voorzitter stuurgroep RAIL Drs. J.Th. Sørensen

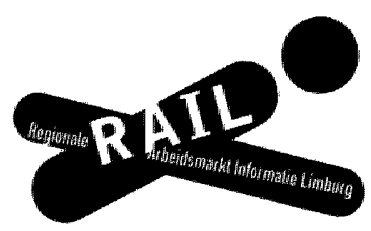

Voorzitter Vertrouwenspact Limburg Gedeputeerde H.FM. Evers 


\section{Verschenen RAlL-publicaties}

98.RAIL-01: De Limburgse arbeidsmarkt 1997-2002; hoofdrapport*

98.RAIL-02: De Limburgse arbeidsmarkt 1997-2002; statistische bijlage*

98.RAIL-03: Kwalitatieve informatie over de Limburgse arbeidsmarkt; werkdocumenten industrie, handel*

99.RAIL-04: De Limburgse arbeidsmarkt 1998-2002; hoofdrapport*

99.RAIL-05: De Limburgse arbeidsmarkt 1998-2002; statistische bijlage*

99.RAIL-06: De Limburgse arbeidsmarkt; sectorrapportage bouw - zakelijke dienstverlening*

99.RAIL-07: De Limburgse arbeidsmarkt 1998-2002; beknopte rapportage*

O0.RAlL-08: De Limburgse arbeidsmarkt 1999-2004; hoofdrapport*

00.RAIL-09: De Limburgse arbeidsmarkt 1999-2004; statistische bijlage*

00.RAIL-10: De Limburgse arbeidsmarkt 1999-2004; sectorrapportage horeca, toerisme $\&$ recreatie en overheid*

00.RAIL-11: De Limburgse arbeidsmarkt 1999-2004; beknopte rapportage*

01.RAIL-12: De Limburgse arbeidsmarkt 2000-2004; hoofdrapport

01.RAIL-13: De Limburgse arbeidsmarkt 2000-2004; statistische bijlage

01.RAIL-14: De Limburgse arbeidsmarkt 2000-2004; rayonrapportage Maastricht en Mergelland

01.RAIL-15: De Limburgse arbeidsmarkt 2000-2004; rayonrapportage Parkstad Limburg*

01.RAlL-16: De Limburgse arbeidsmarkt 2000-2004; rayonrapportage Westelijke Mijnstreek*

01.RAIL-17: De Limburgse arbeidsmarkt 2000-2004; rayonrapportage rayon Roermond*

01.RAIL-18: De Limburgse arbeidlsmarkt 2000-2004; rayonrapportage rayon Weert*

01.RAIL-19: De Limburgse arbeidsmarkt 2000-2004; rayonrapportage rayon Venlo

01.RAlL-20: De Limburgse arbeidsmarkt 2000-2004; rayonrapportage rayon Venray

01.RAll-21: De Limburgse arbeidsmarkt 2000-2004; beknopte rapportage

02.RAIL-22: Naar de arbeidsmarkı zonder grenzen; 2001; eerste ontwikkeljaar**

02.RAIL-23: De Limburgse arbeidsmarkı 2001-2006; hooldrapport

02.RAIL-24: De Limburgse arbeidsmark1 2001-2006; statistische bijlage

02.RAIL-25: De Limburgse arbeidsmarkt 2001-2006; rayonrapportage Maastricht en Mergelland

02.RAIL-26: De Limburgse arbeidsmarkt 2001-2006; rayonrapportage Parkstad Limburg*

02.RAlL-27: De Limburgse arbeidsmarkı 2001-2006; rayonrapportage Westelijke Mijnstreek*

02.RAIL-28: De Limburgse arbeidsmarkı 2001-2006; rayonrapportage rayon Roermond ${ }^{*}$

02.RAlL-29: De Limburgse arbeidsmarkt 2001-2006; rayonrapportage rayon Weerl *

02.RAlL-30: De Limburgse arbeidsmarkt 2001-2006; rayonrapportage rayon Venlo

02.RAlL-31: De Limburgse arbeidsmarkı 2001-2006; rayonrapporlage rayon Venray*

02.RAll-32: De Limburgse arbeidsmarkt 2001-2006; beknopte rapportage

03.RAlL-33: RAIL-Euregionaal 2002: De Euregionale arbeidsmarkı in een conjunctureel dal; managementsamenvatting

03.RAIL-34: RAIL-Euregionaal 2002: De Euregionale arbeidsmarkı in een conjunctureel dal; statistische bijlage 
03.RAlL-35: RAIL euregional 2002; der euregionale Arbeitsmarkt auf konjunktureller Talfahrt, Management-Zusammenfassung

03.RAIL-36: RAIL eurégionall 2002; le marché de l'emploi eurégional dans un creux conjoncturel, synthèse

03.RAll-37: De Limburgse arbeidsmarkt 2002-2006; hoofdrapport

03.RAlL-38: De Limburgse arbeidsmarkt 2002-2006; statistische bijlage

03.RAll-39: De Limburgse arbeidsmarkt 2002-2006; rayonrapportage Maastricht en Mergelland

03.RAlL-40: De Limburgse arbeidsmarkt 2002-2006; rayonrapportage Parkstad Limburg

03.RAlL-41: De Limburgse arbeidsmarkt 2002-2006; rayonrapportage Westelijke Mijnstreek

03.RAIL-42: De Limburgse arbeidsmarkt 2002-2006; rayonrapportage rayon Roermond

03.RAIL-43: De Limburgse arbeidsmarkt 2002-2006; rayonrapportage rayon Weert

03.RAIL-44: De Limburgse arbeidsmarkt 2002-2006; rayonrapportage rayon Venlo

03.RAlL-45: De Limburgse arbeidsmarkt 2002-2006; rayonrapportage rayon Venray

03.RAIL-46: De Limburgse arbeidsmarkt 2002-2006; beknopte rapportage

* Publicatie niet meer in boekvorm verkrijgbaar.

RAIL op internet:

www.railsite.nl 


\section{De Limburgse arbeidsmarkt 2002-2006}

\section{Afnemende economische groei}

De economische groei in Nederland stagneert. Ook Limburg ontkomt niet aan de neergaande conjunctuur. Figuur 1 geeft de dalende trend van de economische groei weer voor Limburg en Nederland. Terwijl in 1997, 1998 en 1999 de economische groei in Limburg hoger lag dan landelijk, is de situatie in 2000 en 2001 net omgekeerd.

De jaren van economische voorspoed zijn voorlopig voorbij. Als gevolg van de afnemende economische groei vinden veel herstructureringen en reorganisaties plaats. Omdat de arbeidsmarkt met enige vertraging reageert zullen de jaren met de grootste scharste op de arbeidsmarkt eveneens voorbij zijn. Werkgevers zullen voor de vacatures die zij niet konden vervullen gedurende de afgelopen jaren, alsnog geschikt personeel proberen aan te stellen. Hierdoor ontstaat er eerst een na-ijl effect aan cle vraagzijde van de arbeidsmarkt vanwege de vacatures die het moeilijkst te vervullen waren. Werkgevers zullen echter vanwege de onzekere conjuncturele ontwikkeling over de hele linie afwachtender zijn met het werven van nieuw personeel dan voorheen.

Figuur 1

De regionale economische groei (jaarlijkse groei van het volume van de toegevoegde waarde), in Limburg en Nederland, 1996-2001

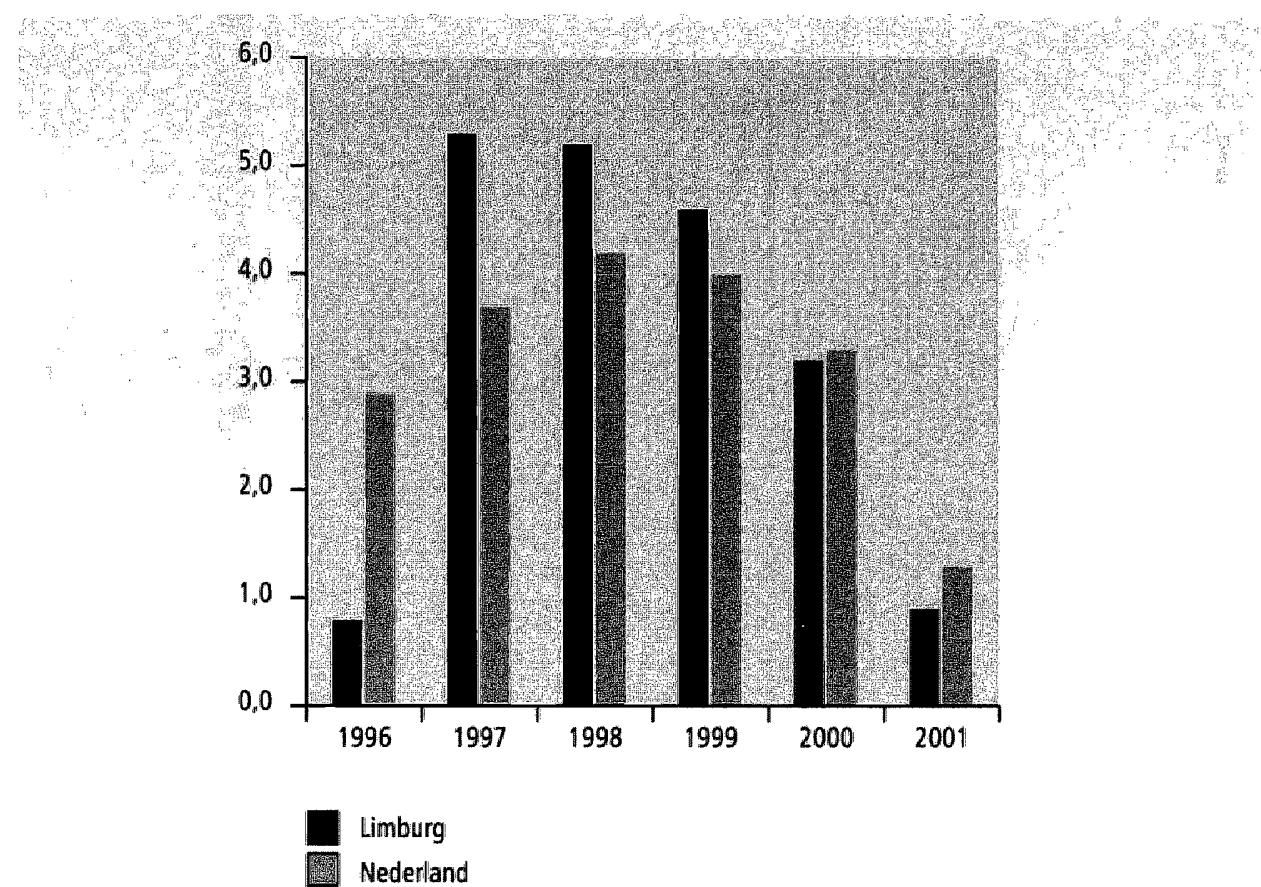




\section{Afnemende werkgelegenheildsgroei}

Veranderingen in de ontwikkeling van de Limburgse werkgelegenheidsgroei zijn op zichzell niet bijzonder. Uit liguur 2 blijkt dat de jaarlijkse groei van het arbeidsvolume in Limburg vanaf 1976 in 1981/82/83 en in 1993/94 een dieptepunt bereikte. Vooral in de eerste periode van werkgelegenheidskrimp werd Limburg bijzonder zwaar getroffen. De tweede periode was qua krimp van de werkgelegenheid minder lang en hevig. Het verschil in de groei van het arbeidsvolume tussen $1993 / 94$ en de topjaren 1989 en 1998 is bijna 4 procentpunten. Uit de figuur blijkt dat deze cyclus van de Limburgse werkgelegenheidsgroei zich in ongeveer 9 jaar heeft volttrokken. De recente daling van de werkgelegenheidsgroei past in een nieuwe cyclus vanal 1998, waarbij de jaren 2002 en 2003 een nieuw dieptepunt zouden kunnen vormen.

Figuur 2

De groel van het arbeidsvolume (jaarlijkse groei in arbeidsjaren van werkenden in voltijdbanen) in Limburg en Nederland, 1976-2002

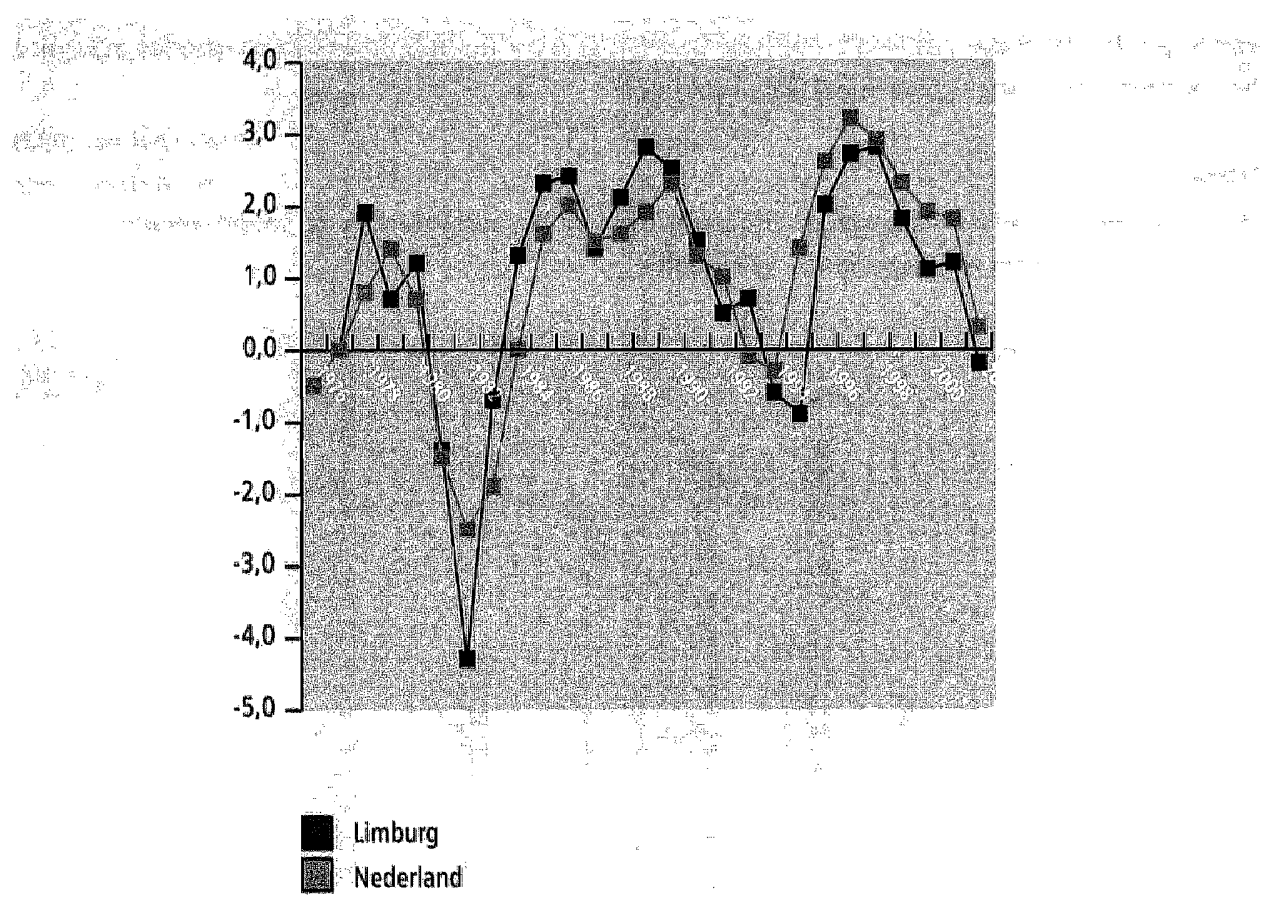

Buml: CBS/CPB/E, il

Voorts blijkt uil de liguur dat de werkgelegenheidsgroei in Limburg sterk samenhangt met die van Nederland. Ook in dit opzicht is de ontwikkeling van de werkgelegenheid in Limburg niet bijzonder. In het algemeen was de Limburgse werkgelegenheidsgroei vanaf het dieptepunt van $1093 / 94$ lager dan de Nederlandse werkgelegenheidsgroei, in tegenstelling tot de periode daarvoor. Men zou voorzichtig kunnen vaststellen dat Limburg zich na 1992 op een lager groeipad bevindt dan Nederland wat betreft de groei van het arbeidsvolume. Er zijn aanwijzingen dat de Limburgse werkgelegenheidontwikkeling iets conjunctuurgevoeliger is dan de Nederlandse vim 1976 tor 1993. Dit blijki uit het feit dat de dalen en de pieken in deze periode 
iets groter zijn voor Limburg, en dat de omslagpunten in de richting van een alname van de werkgelegenheidsgroei voor Limburg iets eerder optreden dan voor Nederland.

Bij een economische neergang verliezen werkenden met een flexibel arbeidscontract het eerst hun baan. Zij kunnen echter relatief snel worden aangenomen als de economie weer aantrekt. Verder kan een inkrimping van het personeelsbestand worden bereikt door ouderen en arbeidsgehandicapten, sneller te laten uitstromen. Deze twee groepen zijn echter moeilijker aan het werk te helpen als de krapte op de arbeidsmarkt weer toeneemt.

\section{Oplopende werkloosheid}

Het aantal niet-werkende werkzoekenden blijkt in 2002 voor het eerst sinds jaren te zijn toegenomen. Hoewel er 6.100 werklozen zijn bijgekomen tussen april 2001 en oktober 2002, is het aantal nog steeds iets kleiner dan in april 2000. In oktober 2002 staat de teller in Limburg op 39.100 niet-werkende werkzoekenden. Een verdere stijging van het aantal werklozen ligt in de lijn der verwachtingen." De laatste jaren is het aantal en het aandeel langdurig werkzoekenden voortdurend gedaald. In februari 1997 bedroeg het aantal langdurig werkzoekenden nog 46.300; in oktober 2002 is dit meer dan gehalveerd tot 1.7.200.

\section{Figuur 3}

Ontwikkeling aantal werkzoekenden en percentage langdurig werkzoekenden, Limburg, 1997-2002

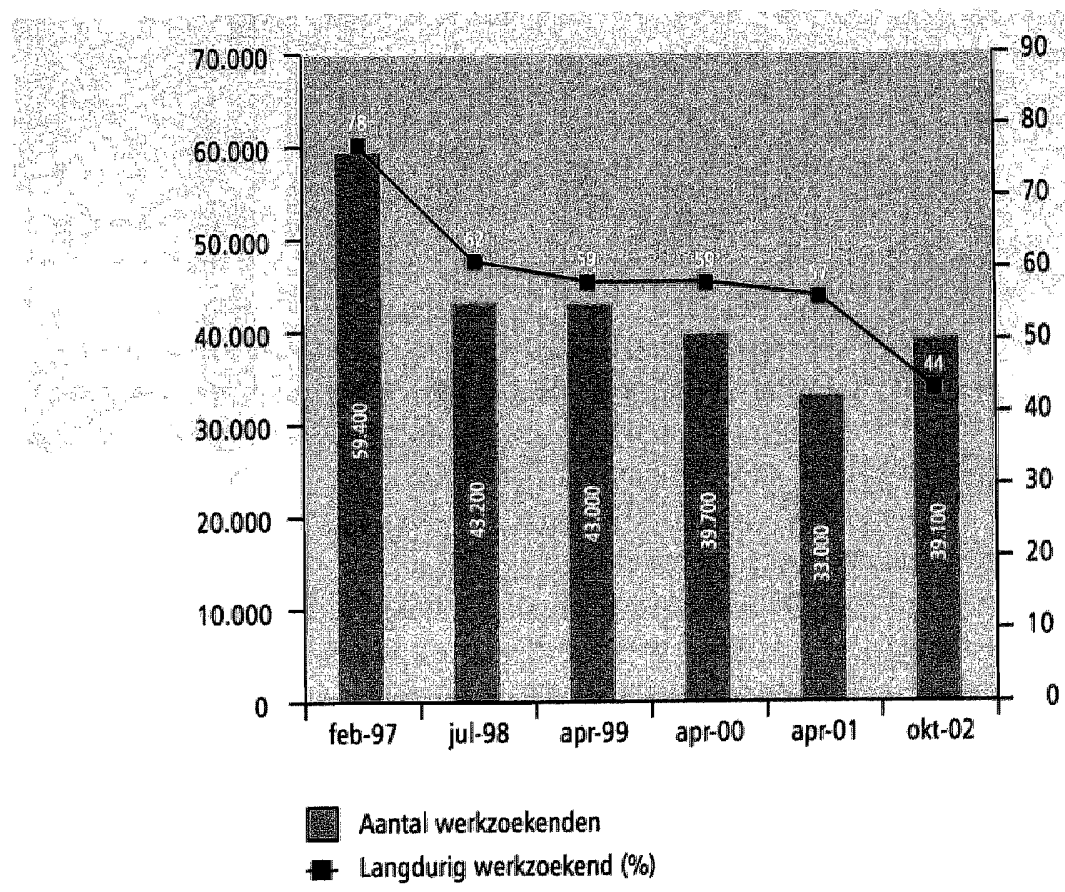

Bron: CWI Zuidoost-Nederland/E, til/ROA

1 Vit CWl-gegevens blijkt dat de werkloosheid on Limburg end jan. 2003 inmiddels is uitgekomen op ea 44 duizend. 


\section{Minder openstaande vacatures.}

Een lagere werkgelegenheidsgroei leidt tot een afname van het aantal vacatures. Na de verdubbeling van het aantal openstaande vacatures tussen februari 1997 en juli 1998, bleef het aantal in de daarop volgende jaren tot en met 2001 schommelen tussen ongeveer 14.000 en 17.000 vacatures. Als gevolg van de economische tegenspoed heeft zich tussen april 2001 en oktober 2002 een sterke daling van het aantal openstaande vacatures voorgedaan. Het aantal openstaande vacatures in Limburg bedraagt in oktober $20027.400 \mathrm{en}$ is daarmee zelfs gedaald onder het niveau van februari 1997 . Een belangrijk verschil met de arbeidsmarktsituatie in 1997 is echter dat de economie zich toen in een opwaartse trend bevond, terwijl er nu van het tegendeel sprake is.

\section{Figuur 4}

Ontwikkelingen aan de vraagzijde van de Limburgse arbeidsmarkt, 1997-2002

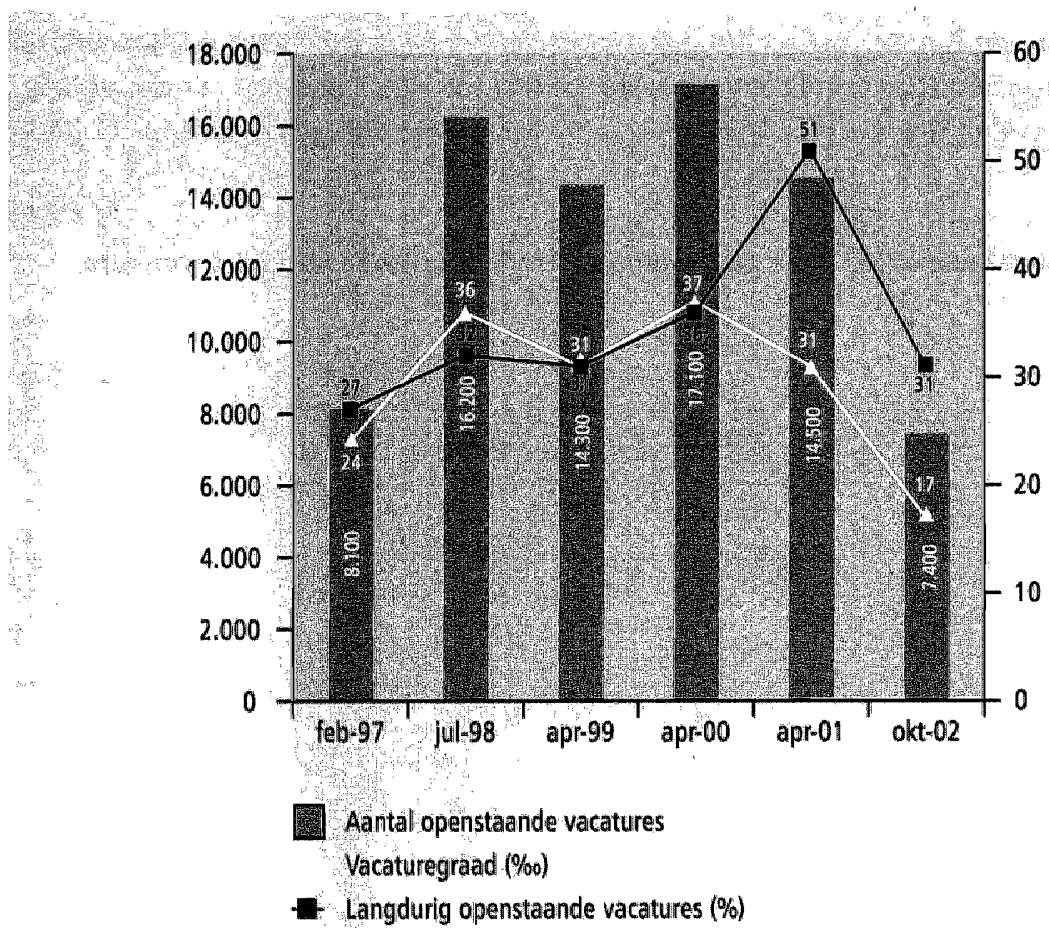

Ook hel antal vacatures per 1.000 werkenden, de vacaturegraad, vertoont een zelfde ontwikkeling. In oktober 2002 zijn er op iedere 1.000 werkenden 17 vacatures, hetgeen 7 promille lager is dan in lebruari 1997. Daarentegen blijft het aantal langdurig openstaande vacatures (i.e. langer dan 3 maanden) als percentage van het totaal aantal openstaande vacatures op een relatief hoog niveau. Nog steeds is bijna eenderde van het aantal openstaande vacatures mocilijk vervulbaar. In 2001 was dat nog de helft. Hel blijkt dat werkgevers ondanks de in het algemeen alnemende werkgelegenheidsgroei en de toename van de werkloosheid tijd nodig hebben om voor deze vacatures geschikt personeel te vinden. 


\section{Dalende krapte}

Gedurende de laatste anderhalf jaar is de arbeidsmarktkrapte aanzienlijk gedaald. Dit komt voor een belangrijk deel door de halvering van het aantal openstaande vacatures. Bovendien is het aantal direct-bemiddelbare werklozen gestegen. In april 2001 laat de arbeidsmarktkrapte een piek zien. Toen stonden tegenover iedere 100 direct-bemiddelbare werkzoekenden maar liefst 251 openstaande vacatures. $\mathrm{Nu}$ is dat aantal geslonken tot slechts 92 openstaande vacatures, hetgeen echter nog altijd beduidend meer is dan in 1997. Voor het eerst sinds jaren staat er niet meer voor elke direct-bemiddelbare werkzoekende een vacature open. De indicator voor de arbeidsmarktkrapte laat duidelijk zien dat de arbeidsmarktsituatie voor werkzoekenden zich na april 2001 sterk heeft verslechterd. voor werkgevers is de overgang naar een meer ontspannen arbeidsmarkt na de jaren van grote knelpunten op zichzelf geen slechte ontwikkeling.

Sinds april 2001 is er ook een kleiner aantal bedrijfssectoren waarin dle arbeidsmarktkrapte zich manifesteert. Alleen in de Landbouw en visserij, de Horeca en zakelijke dienstverlening, de Kwartaire diensten en Overheid en onderwijs heerst er gemiddeld genomen nog arbeidsmarktkrapte. Van belang is dat de arbeidsmarktkrapte binnen de deelsegmenten van de arbeidsmarkt voor de betreffende bedrijfssectoren kan afwijken van de hier gepresenteerde gemiddeldes.

Tabel 1

Krapte op de Limburgse arbeidsmarkt, 1997-2002

\begin{tabular}{|c|c|c|c|c|c|c|}
\hline & februari & juli & april & april & april & okt. \\
\hline & 1997 & 1998 & 1999 & 2000 & 2001 & 2002 \\
\hline Arbeidsmarktkrapte* & 0,39 & 2,22 & 1,91 & 2,34 & 2,51 & 0,92 \\
\hline Aantal bedrijfssectoren met krapte & 0. & 111 & 12 & 12 & 12 & 4 \\
\hline
\end{tabular}

* Arbeidsmarktkrapte $=$ het aantal openstaande vacatures ten opzichte van het aantal direct-bemiddelbare werkzoekenden. Hierbij is niet gecorrigeerd voor seizoenseffecten.

Bron. CWI Zuidoost-Nederland/E,til/CBS/ROA

Stijgende aantal leerlingen in het (V)MBO

Het aantal leerlingen in zowel het Voorbereidend Middelbaar Beroeps Onderwijs (VMBO) als het Middelbaar Beroeps Onderwijs (MBO) vertoont een stijgende trend. Het overgrote deel van de VMBO-leerlingen (meer dan 50.000 leerlingen) volgt de theoretische leerweg of zit in de eerste twee jaar van deze opleiding (de zogenaamde basisvorming). Het aantal leerlingen in het $\mathrm{MBO}$ is, in vergelijking met het jaar 2000, in 2001 gestegen met ruim 1.500 tot boven de 27.000. De sector MBO Dienstverlening en gezondheidszorg is het grootst. Binnen deze sector is het aantal leerlingen ook absoluut gezien het meest gestegen. Maar ook in de sectoren MBO Techniek en MBO Economie neemt het aantal leerlingen toe. Bijna $40 \%$ van de Limburgse MBO'ers volgt een opleiding volgens de meer praktisch georienteerde beroepsbegeleidende leerweg. 


\section{De verwachtingen voor 2003}

De afname in de economische groei zet zich verder door in 2003. In Limburg blijft het groeitempo van de economie lager dan landelijk. Dit betekent ook dat de werkgelegenheidsgroei achterblijft bij de landelijke ontwikkeling.

Er wordt uitgegaan van een werkgelegenheidsgroei voor Limburg van $0,5 \%$ in 2003 . Dit percentage kan echter lager uitvallen als de conjunctuur verder verslechtert. Daarentegen is het aantall baanopeningen dat ontstaat door de uitstroom van personeel van de arbeidsmarkt hoger dan landelijk, mede door de sterkere vergrijzing van de werkende beroepsbevolking in Limburg. In 2003 zullen er voor schoolverlaters in Limburg bijna 25.000 banen beschikbaar zijn. Tegenover een instroom van 23.500 schoolverlaters (incl. hoger opgeleiden) leidt dit tot een vraagoverschot van circa 1.500 personen. Dit is slechts $0,3 \%$ van de werkende beroepsbevolking in Limburg.

Een terugval in de werkgelegenheidsgroei naar de nullijn impliceert dat het vraagoverschot omslaat in een aambodoverschot. Deze mogelijkheid is reëel aanwezig gezien de neerwaartse bijstellingen van de landelijke economische groei en werkgelegenheidsgroei voor 2003 door het Centraal Planbureau. Schoolverlaters lopen bij conjuncturele tegenwind in

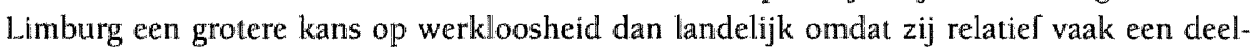
tijdbaan en een flexibele aanstelling hebben. Schoolverlaters zien hun arbeidsmarktkansen derhalve verslechteren. Op de middellange termijn zal naar verwachting de instroom van schoolverlaters op de arbeidsmarkt ontoereikend blijven om in de vraag te kunnen voorzien. Hierdoor zullen de knelpunten op de Limburgse arbeidsmarkt op de middlellange termijn groot blijven.

Tabel 2

Verwachte macro arbeidsmarktontwikkeling (in procenten van de werkgelegenheid) in Limburg in 2003

Kenmerk

$\begin{array}{rr}\text { Limburg } & \text { Limburg } \\ 2003 & 2003 \\ \% & \text { abs. }\end{array}$

Werkgelegenheidsgroei

\begin{tabular}{cc}
\hline 0,5 & 2.500 \\
4,6 & 22.500 \\
5,1 & 25.000 \\
4,8 & 23.500 \\
\hline 0,3 & 1500 \\
\hline
\end{tabular}

Bron: CWI/CPB/ROA

In 2003 zullen er maar lielst 6 van de 13 onderscheiden bedrijfssectoren getroffen worden door een krimp van de werkgelegenheid. Dat de totale werkgelegenheidsgroei nog positief uitvalt is vooral te danken aan de groei in de sectoren Kwartaire diensten, Overheid en onderwijs en Horeca en zakelijke dienstverlening. Dit betekent dat deze sectoren voor 2003 de banenmotor zullen vormen. 
Wanneer de baanopeningen worden afgezet tegen de instroom, zien we dat er in tegenstelling tot de prognoses voor $2002 \mathrm{nu}$ beduidend minder grote knelpunten in de personeelsvoorziening voor werkgevers worden verwacht voor een aantal beroepsklassen. De algemene omslag in de arbeidsmarktsituatie is toe te schrijven aan llinke daling van de verwachte uitbreidingsvraag door de tegenvallende conjunctuur. De vervangingsvraag en de arbeidsmarktinstroom worden uiteraard minder sterk beinnvloed door de conjunctuur. De beroepsklassen waarvoor in 2003 weinig knelpunten worden voorzien zijn de Agrarische beroepen, de Transportberoepen en de Openbare orde en veiligheidsberoepen. Het is echter van groot belang om op te merken dat er binnen deze relatief breed samengestelde beroepsklassen uiteenlopende verwachtingen kunnen gelden ten aanzien van de verschillende beroepsgroepen binnen één beroepsklasse. De grootste knelpunten in de personeelsvoorziening worden in 2003 verwacht voor de Pedagogische beroepen vanwege de sterk achterblijvende instroom van schoolverlaters in deze beroepen. Over het algemeen blijven de perspectieven voor schoolverlaters in 2003 redelijk tot goed. Hierbij is echter de eerder gemaakte kanttekening van een verder verslechterende conjunctuur op zijn plaats. De belangrijkste uitzonderingen op de vooralsnog redelijk tot goede perspectieven vormen schoolverlaters van $M B O$ uiterlijke verzorging en $M B O$ Beweging en therapie die in 2003 op de arbeidsmarkt instromen. $\mathrm{Zij}$ hebben matige respectievelijk slechte arbeidsmarkiperspectieven.

\section{De verwachtingen voor 2006}

Als gevolg van een verwachte geringe economische groei en een krappe arbeidsmarktsituatie wordt in de periode 2001-2006 uitgegaan van een geringe werkgelegenheidsgroei. In Limburg wordt een totale werkgelegenheidsgroei in de periode 2001-2006 verwacht van ongeveer 20.000 banen, ofwel $4 \%$. Dat komt neer op een gemiddelde jaarlijkse werkgelegenheidsgroei van $0,8 \%$, iets minder dan de landelijke groei van $1,2 \%$. Een reden voor dit verschil is dat Limburg relatief meer werk biedt in conjunctuurgevoelige sectoren, die eerder en heviger de gevolgen voelen van een economische neergang.

Tabel 3

Verwachte macro arbeidsmarktontwikkeling (in procenten van de werkglelegenheid), Limburg en Nederland in de periode 2001-2006

Kenmerk

$\begin{array}{rr}\text { Limburg } & \text { Nederland } \\ 2001-2006 & 2001-2006 \\ \% & \%\end{array}$

Werkgelegenheidsgroes

Arbeidsmarktuitstroom 
Verder is de arbeidsmarktuitstroom in Limburg hoger en de instroom van schoolverlaters geringer dan landelijk. Het saldo van baanopeningen en instroom van schoolverlaters resulteert zowel landelijk als in Limburg in een vraagoverschot. Als gevolg van het vraagoverschot is het perspectief voor schoolverlaters op de middellange termijn goed. Alleen voor de culturele beroepen is het beeld iets minder gunstig. De perspectieven zijn het gunstigst voor de medische en paramedische beroepen.

Voor de technische en industrieberoepen, agrarische beroepen, verzorgende en dienstverlenende beroepen en culturelle beroepen worden in 2006 enige knelpunten verwacht. Voor de openbare orde- en veiligheidsberoepen vrijwel geen.

Tabel 4

Typering Indicator Toekomstige Arbeidsmarktperspectieven (ITA) en Typering Indicator Toekomstige Knelpunten in de personeelsvoorziening naar Beroep (ITKB) naar beroepsklasse, in de periode 2001-2006, Limburg

\begin{tabular}{|c|c|c|}
\hline Beroepsklasse & Voor schoolverlaters & Voor werkgevers \\
\hline Pedagogische beroepen & goede perspectieven & grote knelpunten \\
\hline Culturele beraepen & redelijke perspectieven & enige knelpunten \\
\hline Agrarische beroepen & goede perspectieven & enige knelpunten \\
\hline Technische en industrieberoepen & goede perspectieven & enige knelpunten \\
\hline Transportberoepen & goede perspectieven & grote knelpunten \\
\hline Medische en paramedische beroepen & goede perspectieven & grote knelpunten \\
\hline Economisch-administratieve beroepen & goede perspectieven & grote knelpunten \\
\hline Informaticaberoepen & goede perspectíeven & grote knelpunten \\
\hline Sociaal-culturele beroepen & goede perspectieven & grote knelpunten \\
\hline Verzorgende en dienstverlenende beroepen & gioede perspegtieven & enige knelpunten \\
\hline Openbare orde- en veiligheidsberoepen & $\begin{array}{l}\text { goede perspectieven } \\
\text { goederocispectleven. }\end{array}$ & $\begin{array}{l}\text { vriwel geen knelpunten } \\
\text { grote knelpunten. }\end{array}$ \\
\hline
\end{tabular}

Bron. ROA

Voor MBO-niveau en hoger worden er in 2006 over het algemeen gunstige perspectieven voor schoolverlaters verwacht. Minder gunstig zijn de perspectieven voor schoolverlaters met slechts Basisonderwijs of een VMBO-opleiding. Uitgesproken slecht zijn de vooruitzichten voor schoolverlaters van VMBO Landbouw en matuurlijke omgeving en VMBO Economie. Voor VMBO Techniek en VMBO Verzorging zijn de arbeidsmarktperspectieven in 2006 'redelijk'. Deze ontwikkelingen geven aan dat met name de lager opgeleiden geconfronteerd zullen worden met de gevolgen van de minder gunstige ontwikkeling van de Limburgse economie.

Limburgse werkgevers kunnen op de middellange termijn naar verwachting vooral problemen verwachten bij het vinden van geschikt personeel met een $\mathrm{MBO}$-opleiding of hoger. Minder problemen in de personeelsvoorziening worden voorzien voor de lagere opleidingssectoren, met name VMBO Theorie, VMBO Techniek en VMBO Verzorging, terwijl bij het aantrekken van ongeschoold personeel en mensen met VMBO Landbouw en natuurlijke 
omgeving en VMBO Economie de knelpunten op de arbeidsmarkt naar verwachting geheel zullen zijn verdwenen.

Tabel 5

Typering Indicator Toekomstige Arbeidsmarktperspectieven (ITA) en Typering Indicator Toekomstige Knelpunten in de Personeelsvoorziening (ITKP) naar opleidingssector, in de periode 2001-2006, Limburg

Opleidingssector

Basisonderwijs

VMBO Theorie

VMBO Landbouw en natuurlijke orngeving VMBO Techniek

VMBO Economie

VMBO Verzorging

HAVONWO

MBO Landbouw en natuurlijke omgeving

MBO Techniek

MBO Economie

MBO Dienstverlening en gezondheidszorg

Totaal (inclusief HBO en WO)

\author{
Voor schoolverlaters Voor werkgevers
}

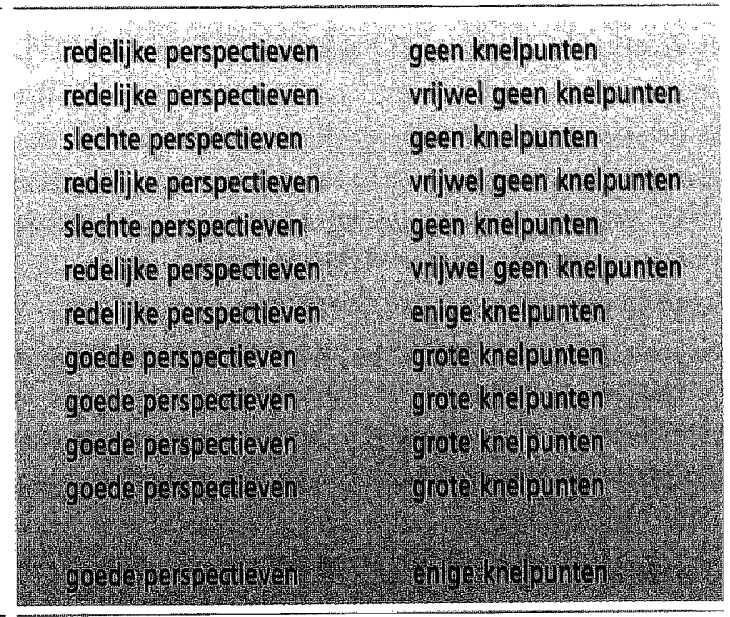

Bron: ROA

\section{Verschillen naar rayon}

De arbeidsmarkt in Limburg is in vergelijking met anderhalf jaar geleden ruimer geworden. Dit is ook in de zeven rayons zichtbaar. De mate waarin dat gebeurd is, verschilt per rayon. Dit hangt samen met de positionering en uitgangspositie van het rayon alsmede met de werkgelegenheidsstructuur.

Het rayon Weert kent een 'open' arbeidsmarkt, een markt die sterk verweven is met de omliggende regio's. In het najaar 2002 is de arbeidsmarkt in Weert krap gebleven. Er zijn niet alleen kwalitatieve discrepanties. Als enig rayon in Limburg zullen ook kwantitatieve discrepanties voelbaar zijn. Op middellange termijn word verwach dat deze arbeidsmarkı weer verder zal verkrappen. De arbeidsmarkt in Venray heeft op hooldlijnen dezelfde kenmerken als die van Weert, met dien verstande dat de discrepanties tot kwalitatieve beperkt blijven.

De arbeidsmarkten van de rayons Venlo, Roermond, Westelijke Mijnstreek en Maastricht \& Mergelland hebben in het najaar 2002 een redelijk ruime arbeidsmarkt. Naast beroepssegmenten met aanbodoverschotten zijn er segmenten met vraagoverschotten. Het gaat veelal om segmenten op hoger niveau in verschillende richtingen. leder rayon heeft een andere uitgangspositie, waardoor ook de middellange termijn er anders uitziet. Zo heeft Venlo cen 
sterk ontwilkkelende markt, waardoor in 2006 weer kwantitatieve discrepanties zullen ontstaan. Roermond heeft juist een meer 'zwakke' markt. Op de middellange termijn neemt de werkgelegenheid weer meer toe, maar dat is ook nodig om de relatief hoge groei van de beroepsbevolking te kunnen volgen. De markı van de Westelijke Mijnstreek is conjunctuurgevoelig, waardoor op middellange termijn de verwachting is dat de werkgelegenheid meer toeneemt dan de beroepsbevolking. Krapte zal weer goed voelbaar worden. De arbeidsmarkt in Maastricht $\&$ Mergelland is dynamisch. In 2006 zal de werkgelegenheid gegroeid zijn en de ruimte op de arbeidsmarkt zal kleiner zijn.

Ten slotte is er het arbeidsmarktrayon Parkstad Limburg. Deze is onevenwichtig. Het aanbod is groter dan de vraag. Dit heeft door de economische teruggang er mede toe geleid dat in het najaar 2002 de arbeidsmarkt ruim is: de ruimste binnen Limburg. Voor de middellange termijn is de verwachting dat de werkgelegenheid meer zal toenemen dan het aanbod. Dit leidt ertoe dat de arbeidsmarkt ook in dit rayon zal verkrappen en minder ruim zal worden. Het is dan weer mogelijk dat er voor bepaalde beroepssegmenten vraagoverschotten zullen ontstaan.

Tabel 6

Algemene typering ${ }^{a}$ van de zeven arbeidsmarktrayons in Limburg', 2002

\begin{tabular}{|c|c|c|c|c|c|c|c|c|}
\hline & Limburg & $\begin{array}{l}\text { Rayon } \\
\text { Venray }\end{array}$ & $\begin{array}{l}\text { Rayon } \\
\text { Venlo }\end{array}$ & $\begin{array}{l}\text { Rayon } \\
\text { Roermond }\end{array}$ & $\begin{array}{l}\text { Rayon } \\
\text { Weert }\end{array}$ & $\begin{array}{l}\text { Rayon } \\
\text { WM }\end{array}$ & $\begin{array}{l}\text { Rayon } \\
\text { PL }\end{array}$ & $\begin{array}{l}\text { Rayon } \\
\text { M\&M }\end{array}$ \\
\hline \multicolumn{9}{|l|}{ Aandeel Limburg } \\
\hline Beroepsbevolking & 100 & 11 & 14 & 13 & 8 & 16 & 22 & 19 \\
\hline Aandeel Limburg & & & & ses: & & & & \\
\hline Werkgelegenheid & 100 & 10 & 15 & 13 & 8 & 15 & 20 & 20 \\
\hline $\begin{array}{l}\text { Werkgelegenheids- } \\
\text { graad }\end{array}$ & (57, & 58,6 & 65,1 & 54,6 & 56,2 & 60,2 & 48,9 & 60,1 \\
\hline Pendelsaldo & 0 & 6.6 & 5,1 & 4,1 & $-10,4$ & 6.6 & 57 & 6,7 \\
\hline Arbeidsparticipatie & 66 & 70 & 68. & 66 & 67. & 65 & 64 & 65 \\
\hline Werkloosheid & 77 & $\begin{array}{r}5,0 \\
5\end{array}$ & & 77 & 5,6 & 7,6 & 101 & 79 \\
\hline Vacaturegraad & 17. & 25 & 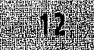 & 16 & 36. & 16 & (11) & 15 \\
\hline
\end{tabular}

a Werkgelegenheid: het aantal banen van ten minste 12 uur per week op basis van VRL 2002.

Werkgelegenheidsgraad: het aantal banen van ten minste 12 uur per week (VRL) ten opzichte van de potentiële beroepsbevolking.

Arbeidsparticipatie: de beroepsbevalking in percentage van de potentiële beroepsbevolking.

Pendelsaldo: saldo van de inkomende en uitgaande pendel t.o.v. de werkgelegenheid.

Werkloosheid: het aantal werklozen (definitie (WI) ten opzichte van de beroepsbevolking.

Vacaturegraad: het aantal openstaande vacatures ten opzichte het 1.000 arbeidsplaatsen van ten minste 12 uur per week.

- $W M=$ Westelijke Mijnstreek, PL=Parkstad Limburg, M\&M=Maastricht \& Mergelland. 


\section{Rayon Venray}

De arbeidsmarkt in het rayon Venray typeert zich als een krachtige markt. In oktober 2002 was de markt nog krap. Er waren meer vacatures dan dat er werklozen in fase 1 beschikbaar waren. Deze discrepanties spitsen zich toe in heel verschillende beroepssegmenten. Vanuit de vraagkant zijn er momenteel tendensen waargenomen die minder positief zijn. Binnen meerdere sectoren vindt herstructurering plaats, waardoor arbeidsplaatsen verloren gaan.

Voor de middellange termijn wordt verwacht dat de ontwikkelingen aan de vraag- en aanbodkant elkaar redelijk in evenwicht zullen houden. De ruimte op de arbeidsmarkt wordt vooral bepaald door de ontwikkeling van de werkloosheid. Als de conjunctuur weer aantrekt dan zal enige tijd later de werkloosheid weer gaan dalen.

\section{Rayon Venlo}

Dit andere rayon in Noord-Limburg kent ook een krachtige arbeidsmarkt. In oktober 2002 was de markt, in tegenstelling tot het rayon Venray, ruim. In algemene zin zijn er meer dan voldoende werklozen in fase 1 om de openstaande vacatures in te vullen. Voor twee beroepssegmenten - hogere pedagogische beroepen en hogere (para)medische beroepen - zijn er onvoldoende werkzoekenden in fase $1 \mathrm{t} / \mathrm{m} 3 \mathrm{om}$ alle vacatures in dat segment vervuld te krijgen. Voor deze segmenten moet dan ook elders geworven worden. Voor de middellange termijn is de verwachting dat de vraag meer toeneemt dan het aanbod. De werkloosheid zal dan ook afnemen. Er mag dan ook van de verwachting uitgegaan worden dat in 2006 in het rayon Venlo weer van een redelijk krappe arbeidsmarkt sprake zal zijn. Naast kwalitatieve discrepanties, zullen de kwantitatieve discrepanties weer voelbaar worden.

\section{Rayon Roermond}

Het rayon Roermond in Midden-Limburg heeft een zwakke arbeidsmarkt. In oktober 2002 was deze markt ook ruim. Alleen voor het hogere medische beroepssegment bestaat een vraagoverschot. Daarnaast komen er voor drie beroepssegmenten omvangrijke aanbodoverschotten voor: Elementaire beroepen, Middelbaar adm.-commerciele beroepen en Lagere adm-commerciéle beroepen. Op middellange termijn wordt verwacht dat de werkgelegenheid weer meer zal gaan toenemen. Dit is ook belangrijk om de relatief hoge groei van de beroepsbevolking te kunnen volgen.

\section{Rayon Weert}

Dit andere rayon in Midden-Limburg karakteriseert zich als een 'open markt'. Bij dit rayon komt de sociaal-economische samenhang en verwevenheid met omliggende rayons het sterkst tot uitdrukking. Het gaat ook om een krachtige markt, die in najaar $2002 \mathrm{krap}$ was. Er zijn nauwelijks voldoende werkzoekenden in fase $1 \mathrm{v} / \mathrm{m} 3 \mathrm{om}$ de vacatures vervuld te krijgen. Er zijn vooral vraagoverschotten voor de middelbaar technische en middelbaar verzorgende beroepen. Voor de toekomst wordt verwacht dat de ontwikkelingen aan vraagen aanbodkant elkaar redelijk in evenwicht zullen houden. De mate van de krapte hangt in dit rayon samen met de ontwikkeling van de werkloosheid. Als de economie weer aantrekl, zal in het rayon Weert de discrepanties weer op meerdere beroepssegmenten merkbaar zijn. 


\section{Rayon Westelijke Mijnstreek}

De arbeidsmarkt van dit rayon in Zuid-Limburg is conjunctuurgevoelig. Dit hangt samen met de werkgelegenheidsstructuur, waarin nijverheid en logistiek sterk vertegenwoordigd zijn. Nu de conjuncturele groei het afgelopen jaar fors verminderd is, is de ruimte op de arbeidsmarkt in najaar 2002 voor dit rayon dan ook redelijk te noemen. Er zijn vooral aanbodoverschotten in de elementaire en administratief-commerciële beroepssegmenten. Er zijn vraagoverschotten in een paar hogere beroepssegmenten. Opvallend hierbij is dat het niet om technische beroepen gaat. De vraag zal op middellange termijn weer gaan toenemen. Het aanbod zal evenwel minder hard groeien. De verwachting is dan ook dat de werkloosheid daalt tot onder het gemiddelde werkloosheidsniveau van 2002.

\section{Rayon Parkstad Limburg}

Deze arbeidsmarkt is nog steeds onevenwichtig. Het aanbod is groter dan de vraag. De werkgelegenheidsontwikkelingen blijven relatief gezien achter. In het najaar 2002 was dan ook sprake van een ruime arbeidsmarkt. Ook op het niveau van beroepssegmenten is er voor (bijna) alle beroepssegmenten sprake van aanbodoverschotten. Voor de elementaire en administratief-commerciële beroepssegmenten zijn deze zelfs omvangrijk. Daarnaast is er geen enkel beroepssegment waarvoor een vraagoverschot bestaat. De verwachting naar 2006 toe is dan ook dat er in het algemeen bezien zich geen kwantitatieve problemen zullen voordoen in dit rayon. De aanbodkant neemt namelijk meer toe dan de vraagkant. Wel kan bij bepaalde beroepssegmenten de ruimte minder worden en aldus kunnen er kwalitatieve discrepanties optreden.

\section{Rayon Maastricht \& Mergelland}

Het rayon Maastricht \& Mergelland in Zuid-Limburg is dynamisch. Zowel de vraag-als de aanbodkant hebben zich de afgelopen jaren sterk ontwikkeld. Door de conjuncturele ontwikkelingen is de werkloosheid gestegen, waardoor er meer ruimte op de arbeidsmarkt is ontstaan. In het najaar 2002 was in dit rayon dan ook sprake van een redelijk ruime arbeidsmarkt: Ondanks de ruime markt, zijn er vraagoverschotten geconstateerd in medisch-verzorgende richtingen en aanbodoverschotten in de elementaire beroepen en administratiel-commerciele beroepen. Naar 2006 toe wordt verwacht dat de werkgelegenheid weer meer gaat toenemen. De ruimte op deze regionale arbeidsmarkt neemt af. De werkloosheid zal weer afnemen en tot onder het niveau van het jaar 2002 dalen. 


\section{Samenvatting en conclusie}

De vorig jaar reeds geconstateerde afname van de economische groei heeft zich duidelijk vertaald in de huidige arbeidsmarktsituatie. In 2002 is het aantal openstaande vacatures met ongeveer de helft afgenomen, terwijl het aantal werkzoekenden flink toeneemt. De arbeidsmarktkrapte blijkt in 2002 dan ook aanzienlijk te zijn gedaald. Terwijl in april 2001 tegenover iedere 100 direct bemiddelbare werkzoekenden maar liefst 251 openstaande vacatures stonden, is dat aantal in oktober 2002 gedaald tot 92 .

Op middellange termijn worden er evenwel gunstige arbeidsmarktperspectieven voor schoolverlaters van het $\mathrm{MBO}$ of hoger verwacht, tegenover minder gunstige perspectieven voor schoolverlaters met slechts Basisonderwijs of een VMBO-opleiding. Daarbij komen wel verschillen tussen de diverse richtingen voor. Deze gunstige perspectieven voor middelbaar of hoger opgeleiden op middellange termijn wordt met name veroorzaakt door de hoge vervangingsvraag (vergrijzing) en de voortdurende stijging van de opleidingseisen.

De arbeidsmarkt blijft in beweging. Dit noodzaakt tot het voortdurende peilen van de arbeidsmarktontwikkelingen en het bijstellen van het arbeidsmarktbeleid in Limburg. 